ISSN : $1410-7252$

Vol. 18 No. 01 Juni 2016

\title{
PENGEMBANGAN EKOWISATA PANTAI SEBAGAI DIVERSIFIKASI MATA PENCAHARIAN
}

\author{
Bambang Supriadi \\ Program Diploma Kepariwisataan Universitas Merdeka Malang \\ Jl. Bandung No. 1 Malang
}

Korespodensi dengan Penulis:

Bambang Supriadi: Telp: 08125262526

E-mail: bambang.unmer@gmail.com

\begin{abstract}
The quality of human resources are now in the poor level. By the diversification of people livelihoods (especially in ecotourism), it is possible to minimize the pressure on human resources. The purposes of this study are: 1 . To analyze the social condition, economic and cultural community in the coastal resorts of South Malang Regency, 2. To describe a potential beach that has a chance to grow (development), 3. To describe the weakness and resistance of Tourist attraction management (planning and utilization), 4. To describe the opportunities of job opportunities in the sector of tourism services that will be utilized by the community around the tourist attraction area. Research methodology which was used in this study was Partisipatory Rural Appraisal approach (PRA), FGD (Focused Group Discussion), and SWOT. The target to be achieved in this study are: Knowing the strengths and weaknesses of Goa China beach when it is managed properly and professionally, Knowing the types of new tourism business opportunities which will be utilized for improvished families as employment opportunities (Guide, souvenirs seller, food and beverage sellers, etc.), and as policy recommendations on the development of coastal tourism to the government. The final conclusion is that the Tourist Attraction of Goa China has a negative value (-0.45) for the internal environment and a negative value (-0.35) for the external environment. Thus can be deduced that the position Goa China on Third Quadrant (difensif position). And it requires physical development, clean environment, and more public facilities, alternative businesses which needs to grow is mangrove cultivation and turtles breeding, and providing home stay, Internet network, and provision of unique souvenirs.
\end{abstract}

Keywords : Human Resources, Eco-tourism, Diversification, Livelihood

\begin{abstract}
Abstraksi
Kualitas sumber daya manusia berada pada persepsi kurangnya keterampilan usaha dan berdampak pada kurangnya jenis mata pencaharian. Dengan diversifikasi mata pencaharian masyarakat (terutama terhadap jenis ekowisata), adalah mungkin untuk meminimalkan tekanan pada sumber daya manusia. Dengan demikian harapan penelitian ini adalah : 1. Menganalisis kondisi sosial, ekonomi dan budaya masyarakat yang berada di kawasan wisata pantai Kabupaten Malang Selatan, 2. Mendeksripsikan potensi-potensi Wisata Pantai yang mempunyai peluang untuk ditumbuh kembangkan (the development), 3 . Mendeksripsikan Kelemahan dan hambatan pengelolaan (perencanaan dan
\end{abstract}


pemanfaatan) Wisata Pantai, 4. Mendiskripsikan kesempatan peluang kerja baru di sektor jasa wisata yang akan di manfaatkan oleh masyarakat di sekitar kawasan Wisata Pantai.Metode analisis untuk menjawab tujuan diatas menggunakan pendekatan Patisipatory Rural Appraisal (PRA), FGD (Focused Group Discusion), kemudian dilanjutkan dengan melakukan Analisis SWOT.Target yang ingin di capai dalam penelitian ini adalah : Mengetahui kekuatan dan kelemahan Pantai Gua Cina apa bila di kelola secara baik dan profesional, Mengetahui jenis-jenis kesempatan usaha wisata baru yang akan di manfaatkan bagi keluarga prasejahtera sebagai peluang kerja (Guide, Pedagang cinderamata, Penjual makanan dan minuman, dll), dan sebagai Rekomendasi kebijakan pengembangan wisata pantai pada Pemerintah. Dari hasil penelitian disimpulkan bahwa DTW (Daya Tarik Wisata) Gua cina memiliki nilai negatif($0,45)$ untuk lingkungan internal dan nilai negatif $(-0,35)$ untuk lingkungan eksternal. Dengan demikian dapat di tarik kesimpulan bahwa posisi DTW Gua Cina masuk pada kuadran 3 (Tiga) yang artinya posisi ini pada posisi difensif. Dan dibutuhkan pembangunan fisik, lingkungan yang bersih, dan menambah fasilitas-fasilitas umum pariwisata,alternatif usaha yang perlu tumbuh kembang kembangkan adalah devirsifikasi pengelolahan budidaya mangrove dan pengankaran penyu, dan aktifitas pramuwisata oleh kelompok masyarakat pesisir pantai dan jangka menengah penyediaan home stay, jaringan internet, dan penyediaan cindera.

Kata kunci: Sumberdaya Manusia, Ekowisata, Diversifikasi, Lapangan Perkerjaan

Pengelolahan wisata pantai sebagai sumber daya alam jika tidak dibuat manejemen dengan baik maka akan merugikan masyarakat sebagai alternatif mata pencaharian, menurut Eshetu (2014). Sumber daya alam di negara-negara berkembang berada di bawah ancaman besar sebagian karena kurangnya alternatif dan sebagian karena jenis mata pencaharian masyarakat. Dengan diversifikasi mata pencaharian masyarakat (terutama terhadap ecofriendly jenis), adalah mungkin untuk meminimalkan tekanan pada sumber daya alam.
Sejalan dengan ini Ide, ekowisata sebagai kegiatan ekonomi memungkinkan kedua untuk diversifikasi mata pencaharian dan berkelanjutan mengelola sumber daya alam menanggulangi kemiskinan

Pemanfaatan pantai sebgai sumber daya alam merupakan dasar sosial dan pembangunan ekonomi untuk pengurangan kemiskinan, sesuai dengan pendapatnya kementerian Keuangan dan Perkembangan Ekonomi ( Ministry of Finance and Economic Development/MoFED, menjelaskan 
Sumber daya lingkungan merupakan dasar sosial dan pembangunan ekonomi karena mereka adalah sumber barang dan jasa yang diperlukan untuk pengurangan kemiskinan dan pertumbuhan ekonomi. Pemanfaatan linkungan mereka sejauh ini telah mengurangi kontribusi mereka untuk pembangunan secara keseluruhan (MoFED, 2006).

Seperti Negara Indonesia yaitu negara berkembang harus mengutamakan pembangunan berkelanjutan hal ini penting untuk mengintegrasikan masalah lingkungan sejalan dengan kebijakan (EPA/Environmental Protection Authority,2000), dalam rangka untuk memastikan bahwa perkembangan masa depan di Negara berkembang yang berkelanjutan adalah penting untuk mengintegrasikan masalah lingkungan menjadi kegiatan pembangunan sehingga masuknya prinsip-prinsip pembangunan berkelanjutan ke dalam pembangunan upaya ini sangat penting.

Dengan demikian, ekowisata dapat memainkan peran sentral dalam konservasi dan pembangunan pedesaan (Nelson, 2004) yang biasanya pendekatan ecopembangunan di pengelolaan sumber daya alam. dan menekankan kebutuhan untuk merestrukturisasi masyarakat dan ekonomi untuk memastikan pembangunan yang bekerja dengan baik, bukan merusak, alam. sehingga hubungan antara masyarakat dan alam di hasil paradigma eco-development dengan reorganisasi aktivitas manusia sehingga menjadi sinergis dengan alam.

Dengan demikian jika sumberdaya alam ini tidak akan bermanfaat untuk bisa menanggulangi kemiskinan, karena masyarakat miskin merupakan masalah yang penting saat, sehingga menjadi fokus perhatian bagi pemerintah Daerah . Masalah masyarakat miskin ini sangatlah kompleks dan bersifat multidimensional, dimana berkaitan dengan aspek sosial, ekonomi, budaya, keamanan dan aspek lainnya. Kemiskinan terus menjadi masalah fenomenal di setiap provinsi di Indonesia, khususnya Jawa Timur. Kemiskinan telah membuat jutaan anak tidak bisa mengenyam 
pendidikan, kesulitan membiayai kesehatan, kurangnya tabungan dan investasi, dan masalah lain yang menjurus ke arah tindakan kekerasan dan kejahatan.

Kemiskinan yang terjadi dalam suatu daerah memang perlu dilihat sebagai suatu masalah yang sangat serius, karena saat ini kemiskinan, membuat banyak masyarakat mengalami kesusahan dalam memenuhi kebutuhan hidupnya. Persoalan kemiskinan ini lebih dipicu karena masih banyaknya masyarakat yang mengalami pengangguran dalam bekerja. Pengangguran yang dialami sebagian masyarakat inilah yang membuat sulitnya dalam memenuhi kebutuhan hidupnya, sehingga angka kemiskinan selalu ada dan bahkan bertambah.

Kemiskinan di Indonesia pada bulan September 2012, jumlah penduduk miskin (penduduk dengan pengeluaran per kapita per bulan di bawah Garis Kemiskinan) mencapai 28,59 juta orang $(11,66 \%)$, Bulan Maret 2012 Provinsi Jawa Timur menempati urutan pertama di Indonesia jumlah penduduk miskin Kota dan Desa sebesar $\quad 5.070 .980$ dan khusus
Kabupaten Malang berada dalam kondisi kelompok besar sebagai wilayah termiskin di Jawa Timur dengan jumlah 86.406 keluarga miskin / Rumah Tangga dengan kategori miskin (Dinas Sosial Kabupaten Malang,2011). Dan sementara itu Kabupaten Malang di tahun yang sama 2011 terdapat 470 Anak balita terlantar dan mengalami gizi buruk dan di perparah lagi sebanyak 11.052 Keluarga rumah tak layak huni (Properiess Home) sehingga Masalah sosial di Kabupaten Malang sangat memerlukan perhatian untuk mendorong percepatan perubahan kehidupan masyarakat dan pengentasan kemiskinan dengan menciptakan peluang kerja baru melalui pengelolaan potensi wisata yang bisa di kembangkan hingga mencapai taraf kesejahteraan yang di harapkan. Perhatian ini berhubung kondisi kemiskinan akan berdampingan dengan kondisi rentan social dan ancaman terhadap buruknya keamanan sosial (Rentan social), kesehatan dan layanan kesehatan, kerentanan meningkatnya angka putus sekolah/tidak sekolah, kerentanan kematian ibu dan anak 
yang seiring dengan perkembangan gizi buruk yang berakibat pada lambatnya kecerdasan generasi muda di masa akan datang.

Seiring dengan amanah

Peraturan Menteri Dalam Negeri No 33 Tahun 2009 Tentang Pedoman Pengembangan Ekowisata Di Daerah (Wisata bahari, Hutan dan Karst). Maka di buat salah satu prinsip pengembangan wisata pantai sebagai berikut: Bersifat ekonomis yaitu memberikan manfaat untuk masyarakat setempat dan menjadi penggerak pembangunan ekonomi di wilayahnya serta memastikan usaha ini dapat berkelanjutan dan mendorong aktif partisipasi masyarakat, yaitu peran serta masyarakat dalam kegiatan perencanaan, pemanfaatan, dan pengendalian wisata dengan menghormati nilai-nilai sosial-budaya dan keagamaan masyarakat di sekitar kawasan wisata, mengandung unsur pendidikan untuk mengubah persepsi seseorang agar memiliki kepedulian, tanggung jawab, dan komitmen terhadap pelestarian lingkungan dan budaya, melindungi, mengawetkan, dan memanfaatkan secara lestari sumberdaya alam yang digunakan.

Untuk pengembangan sebuah kawasan harus bertitik tolak dari pengembangan nilai-nilai yang bertumpu pada beberapa hal antara lain: (a) Masyarakat menjadi subyek sehingga harus dilibatkan, Pelestarian daerah bernilai sejarah, sosial dan budaya, (c) Pengembangan kawasan terpadu modern dan tradisional untuk melestarikan keberadaan kampung sebagai bagian sebuah daerah. (JurnalImiah Pariwisata, November 2008, Vol. 13 No. 3. hal 208 - 22506)

Dalam konteks kebutuhan tersebut, konsep Pengelolaan Wisata Pantai perlu dipahami bersama untuk menyelesaikan persoalan yang terkait dengan kondisi kemiskinan yang terjadi di wilayah Kabupaten Malang. Pengelolaan segala potensi Wisata Pantai Gua Cina di Kabupaten Malang sebagai salah satu alternative upaya mengatasi kemiskinan masyarakat khususnya pada masyarakt sekitar obyek dan daya tarik wisata tersebut.. Oleh karena itu, Penelitian ini diharapkan dalam upaya menekan angka kemiskinan tersebut melalui 
kegiatan Pengelolaan Wisata Pantai yang disusun secara strategis.

\section{Tujuan dalam penelitian ini adalah :}

1. Menganalisis kondisi sosial, ekonomi dan budaya masyarakat yang berada kawasan wisata Gua Cina.

2. Mendeksripsikan potensi-potensi Wisata Pantai Gua Cina yang mempunyai peluang untuk ditumbuh kembangkan (the development)

3. Mendeksripsikan Kelemahan dan hambatan pengelolaan (perencanaan dan pemanfaatan) Wisata Pantai Gua Cina

4. Analisis dan mendeskripsikan kesempatan peluang kerja di sektor wisata yang akan di manfaatkan oleh masyarakat miskin sekitar kawasan Wisata Pantai Gua Cina.

\section{Urgensi (Keutamaan) Penelitian}

Kabupaten Malang adalah kota yang memiliki potensi pariwisata (wisata pantai, wisata gunung dan wisata hutan) yang sangat menjanjikan jika dikembangkan dan dikelola secara baik dan profesional, Kabupaten Malang salah satu kota masuk dalam konsep KSPN (Kawasan Strategis Pariwisata Nasional ) di dalam RIPPARNAS (Rencana Induk Kepariwisataan Nasional) Tahun 2010 $-2025$.

Namun demikian potensi wisata tersebut diatas masih belum berpengaruh signifikan terhadap kesejahteraan masyarakat di Kabupaten Malang, hal ini terbukti bahwa Kabupaten Malang masih masuk dalam kelompok besar kabupaten di Jatim yang memiliki jumlah kantong-kantong kemiskinan. Jumlah warga miskin di Kabupaten Malang saat ini tahun 2012 mencapai jumlah 86.406 keluarga miskin / Rumah Tangga dengan kategori miskin (Dinas Sosial Kabupaten Malang,2011).

Atas dasar kesejangan (gap) problematik di atas perlu dicarikan alternatif pemecahaannya melalui kegiatan penelitian, di sinilah urgensi dari penelitian kali ini, dengan demikian masalah penelitian ini dapat dirumuskan secara spesifik sebagai berikut:

1. Bagaimana kondisi sosial, ekonomi dan budaya masyarakat 
yang berada kawasan wisata Gua Cina Kab. Malang?

2. Apa saja Kekuatan dan kelemahan Pantai Gua Cina apa bila di kelola secara baik dan profesional?

3. Bagaimana menciptakan peluang kerja di sektor jasa wisata (Guide, Pedagang cinderamata, Penjual makanan dan minuman, dll) yang dapat di manfaatkan oleh masyarakat miskin di sekitar kawasan wisata pantai tersebut?

\section{METODE}

Lokasi penelitian ini dilakukan di Obyek Daya Tarik Wisata Pantai Gua Cina Kecamatan Gedangan Kabupaten Malang. Sekitar 58 Kilo meter arah selatan Kota Malang, Tahapan Penelitian, Tahapan penelitian terdiri dari empat (4) tahap mengacu pada tahapan yaitu persiapan, teknik pengumpulan data, survey dan analisis data:

1. Tahap Persiapan, meliputi komponen kegiatan sebagai berikut: Tahap persiapan pada tahapan penelitian dimulai dengan menyusun usulan penelitian yang akan di lakukan dan mempersiapkan pengurusan izin untuk melaksanakan penelitian.

2. Tahap Studi Literatur yaitu Kegiatan studi literatur mengenahi:

a. Kajian Literatur tentang manajemen pengelolaan obyek dan daya tarik wisata pantai di Kabupaten Malang, kajian literature/ konsep mengenai kepariwisataan seperti konsep pengembangan wisata bahari / pantai.

b. Kajian Kebijakan Kepariwisataan Nasional dan Regional yaitu kajian mengenai UU No 10 tahun 2009 Tentang Kepariwisataan, dan kajian RIPPARNAS (Rencana Induk Pembangunan Kepariwisataan Nasional Tahun 2010 - 2025) dan kajian RIPDA (Rencana Induk Pariwisata Daerah) Kabupaten Malang

3. Teknik Pengumpulan Data yaitu Teknik Sensus kepada keluarga Prasejahtera di area obyek wisata dan survei data sekunder yang ada di instansi dan Kantor Desa di wilayah obyek wisata pantai Gua Cina. Teknik pengumpulan data 
(primer) digunakan pendekatan wawancara dengan menggunakan daftar pertanyaan (quesioner) dan participatory research (diskusi kelompok dan wawancara kepada key persons).

4. Analisis dan Interpretasi Data.

a. Analisis penelitian ini menggunakan Formulasi :

b. SPSS (Statistical Program For Social Science),

c. FGD (Focused Group Discusion) dan Patisipatory Rural Appraisal (PRA) yaitu diskusi terhadap pemahaman desa/wilayah secara partisipasi. menyangkut Analisis kondisi sosial ekonomi masyarakat di sekitar pantai, dan mencari serta mengidentifikasi peluang kesempatan kerja di sector wisata.

d. Analisis SWOT yaitu Salah satu tehnik analisa yang digunakan untuk menganalisa kondisi lingkungan Obyek wisata pantai Gua Cina secara internal dan eksternal Kabupaten Malang yaitu analisis SWOT (Strenght, Weakness, Opportunity dan Threats). Analisa ini memformulasikan tentang Kekuatan,Kelemahan, Peluang dan Ancaman termasuk di dalamnya faktor penunjang dan penghambat dari lingkungan internal maupun eksternal konsep pengembangan wisata pantai Gua Cina di Kabupaten Malang. Sekaligus membuat interpretasi data yaitu mengaitkan temuan-temua (data) dengan hasil kajian pustaka atau teori terkait.

\section{HASIL DAN PEMBAHASAN}

Sejarah pantai Gua Cinayang terletak di Dusun Trowotratih, Desa Sitiarjo, Kecamatan Sumbermanjing Wetan, sekitar 3 jam dari Kota Malang. Sekitar tahun 1930-an, seorang pengembara Tionghoa dari Surabaya bernama Hing Hook, terdampar di sebuah pantai tersembunyi di Malang Selatan. Hatinya gundah gulana karena kemiskinan yang terus menderanya.Ia kemudian bertapa di sebuah gua yang berada di salah satu pulau kecil yang ada di sana. Sendirian, tak ada yang menemani. Mungkin ia ingin mengadukan nasib jeleknya kepada yang Maha Kuasa. 
ISSN : $1410-7252$

Vol. 18 No. 01 Juni 2016

Sebelum mendapatkan apa yang dicari, maut menjemputnya. Ia meninggal dalam kesepian di gua itu. Jasadnya ditemukan beberapa hari kemudian oleh penduduk sekitar dan dimakamkan di tempat lain. Sejak saat itu, pantai tersebut dinamakan Pantai

Gua

Cina.

Tabel 1. Prasarana Daya Tarik Wisata

\begin{tabular}{|c|c|c|}
\hline Indikator & Kekuatan & Kelemahan \\
\hline Kondisi jalan di DTW & $\begin{array}{l}\text { Kondisi jalan utama } \\
\text { menuju Pantai Gua } \\
\text { Cina cukup baik, tapi } \\
\text { kondisi jalan menuju } \\
\text { lokasi Obyek Wisata } \\
\text { Pantai masih tanah } \\
\text { dan berbatu yang } \\
\text { belum di aspal }\end{array}$ & \\
\hline Sarana Transpotasi Umum & & $\begin{array}{l}\text { Sarana transportasi umum untuk } \\
\text { menuju Obyek Wisata Pantai } \\
\text { belum ada }\end{array}$ \\
\hline $\begin{array}{l}\text { Kondisi Kejernihan Air di } \\
\text { DTW }\end{array}$ & $\begin{array}{l}\text { Kondisi Kejernihan } \\
\text { Air sebagian besar } \\
\text { sangat baik }\end{array}$ & \\
\hline Toilet & $\begin{array}{l}\text { Memiliki jumlah toilet } \\
\text { yang cukup }\end{array}$ & \\
\hline $\begin{array}{l}\text { Petujuk Jalan atau Sign } \\
\text { system }\end{array}$ & $\begin{array}{l}\text { Memiliki petunjuk } \\
\text { arah disepanjang jalan } \\
\text { menuju DTW }\end{array}$ & \\
\hline Kebersihan di DTW & & $\begin{array}{l}\text { Kondisi lingkungan DTW yang } \\
\text { masih kurang bersih }\end{array}$ \\
\hline $\begin{array}{l}\text { Tempat } \quad \text { Pembuangan } \\
\text { Sampah }\end{array}$ & $\begin{array}{l}\text { Memiliki Tong } \\
\text { sampah yang cukup }\end{array}$ & \\
\hline $\begin{array}{l}\text { Area Parkir yang Luas } \\
\text { khususnya untuk bis }\end{array}$ & $\begin{array}{l}\text { Memiliki lahan parkir } \\
\text { yang cukup luas } \\
\text { sehingga bisa untuk } \\
\text { beberapa bis dan } \\
\text { kendaraan lainnya. }\end{array}$ & \\
\hline $\begin{array}{l}\text { Penerangan Jalan Ketika } \\
\text { Malam hari }\end{array}$ & & $\begin{array}{l}\text { Tidak memiliki penerangan jalan } \\
\text { sepanjang DTW ketika malam hari }\end{array}$ \\
\hline
\end{tabular}

Tabel 2. Sarana Daya Tarik Wisata

\begin{tabular}{ccc}
\hline \multicolumn{1}{c}{ Indikator } & Kekuatan & \multicolumn{2}{c}{ Kelemahan } \\
\hline Souvenir khas daerah & Masih belum ada tindak lanjut \\
\hline
\end{tabular}


ISSN : $1410-7252$

Vol. 18 No. 01 Juni 2016

\section{PESONA}

\begin{tabular}{|c|c|c|}
\hline & & $\begin{array}{l}\text { tentang pembuatan cindera mata } \\
\text { khas pantai tersebut }\end{array}$ \\
\hline Warung sekitar DTW & $\begin{array}{l}\text { Sudah baik, perlu di } \\
\text { tingkatkan tentang } \\
\text { kebersihan makanan di } \\
\text { DTW tersebut.harga } \\
\text { relatif murah }\end{array}$ & \\
\hline Agen Perjalanan & & Masih belum ada agen perjalanan \\
\hline Tempat Bersantai & $\begin{array}{l}\text { Baik,Tempat bersantai } \\
\text { perlu di perbanyak lagi } \\
\text { agar wisatawan dapat } \\
\text { menikmati keindahan } \\
\text { pantai tersebut. Selain itu } \\
\text { tempat tersebut } \\
\text { memanfaatkan pohon } \\
\text { kelapa dan } \\
\text { memanfaatkan alam }\end{array}$ & \\
\hline $\begin{array}{l}\text { Atraksi dan Hiburan } \\
\text { lain }\end{array}$ & & $\begin{array}{l}\text { Tidak terdapat hiburan lain dan } \\
\text { atraksi budaya yang d perliatkan oleh } \\
\text { warga sekitar. }\end{array}$ \\
\hline Internet & & $\begin{array}{l}\text { Tidak terdapat layanan internet di } \\
\text { DTW tersebut. }\end{array}$ \\
\hline
\end{tabular}

$\begin{array}{ll}\text { Jaringan Telepon } & \\ \text { Kondisi Masjid } & \begin{array}{l}\text { Kondisi masjid sudah } \\ \text { baik dan masih tahap } \\ \text { renovasi di sana }\end{array}\end{array}$

Jaringan telepon kurang baik di DTW tersebut.

Masih belum ada ATM di DTW tersebut

Hotel atau Penginapan

Masih belum terdapat hotel maupun penginaman karena wisatawan biasa melakukan campign di tempat tersebut

Pos Kesehatan

Tidak memiliki pos kesehatan di DTW tersebut

$\begin{array}{llr}\text { Pos Keamanan } & \begin{array}{l}\text { Sudah cukup baik dan } \\ \text { perlu ditingkatkan lagi } \\ \text { untuk menciptakan } \\ \text { suasana aman di DTW } \\ \text { tersebut. }\end{array} \\ \text { Asuransi Tiket } & \begin{array}{l}\text { Sudah berjalan dengan } \\ \text { baik dan }\end{array} & \text { sudah } \\ & \text { diterapkan } & \text { kepada }\end{array}$


ISSN : $1410-7252$

Vol. 18 No. 01 Juni 2016

\section{PESONA}

wisatawan yang datang

TIC

Sudah memiliki tempat tersebut tapi

masih banyak yang perlu di

perhatikan

Jumlah wisatawan $:$ Senin-Kamis $=75-100$ wisatawan

Jumat-Minggu $=150-250$ wisatawan

Kecuali bulan januari - maret di karenakan cuaca

yang kurang baik.

Tabel 3. Lingkungan Eksternal

\begin{tabular}{|c|c|c|}
\hline Indikator & Peluang & Ancaman \\
\hline Kondisi Pesaing & & $\begin{array}{l}\text { Kondisi pesaing daya tarik } \\
\text { wisata Gua Cina sangat } \\
\text { tinggi.Hal ini di buktikan } \\
\text { karena } \\
\text { pesaing yang memiliki } \\
\text { keindahan dan kecukupan } \\
\text { pada sarana dan prasana. } \\
\text { Misalnya: pantai bajul mati } \\
\text { dan Pantai Sendang Biru }\end{array}$ \\
\hline $\begin{array}{l}\text { Kebijakan Pemerintah Kabupaten } \\
\text { Malang }\end{array}$ & $\begin{array}{l}\text { Kebijakan Pemerintah } \\
\text { Kabupaten Malang telah } \\
\text { banyak mendukung terhadap } \\
\text { perkembangan sarana dan } \\
\text { prasarana di daya tarik wisata } \\
\text { Gua cina ini. Salah satu } \\
\text { buktinya adalah Gua cina di } \\
\text { masukan dalam Rencana } \\
\text { pengembangan Pariwisata } \\
\text { berbasis Ekowisata }\end{array}$ & \\
\hline $\begin{array}{l}\text { Karakteristik } \quad \text { Peran } \quad \text { serta } \\
\text { Masyarakat }\end{array}$ & & $\begin{array}{l}\text { Karakteristik Peran serta } \\
\text { Masyarakat daya tarik } \\
\text { wisata Gua cina ini sangat } \\
\text { rendah dikarenakan } \\
\text { masyarakat sekitar wisata } \\
\text { enggan untuk turut } \\
\text { berperan } \\
\begin{array}{l}\text { pengembangan daya tarik } \\
\text { wisata }\end{array}\end{array}$ \\
\hline
\end{tabular}

Tabel 4. Total Nilai Tertimbang Daerah Tujuan Wisata Gua Cina

$\begin{array}{cccc}\begin{array}{c}\text { Katagori Variabel dan } \\ \text { Indikator }\end{array} & \text { Bobot } & \text { Nilai } & \begin{array}{c}\text { Nilai } \\ \text { Tertimbang }\end{array}\end{array}$

Kekuatan Daya Tarik Wisata

\begin{tabular}{lllc} 
Keindahan Alam Di Objek Wisata & 0,25 & 5 & 1,25 \\
\hline Keunikan Daya Tarik Wisata & 0,25 & 4 & 1 \\
\hline
\end{tabular}


ISSN : $1410-7252$

Vol. 18 No. 01 Juni 2016

\begin{tabular}{|c|c|c|c|}
\hline Lokasi Daya Traik Wisata & 0,25 & 3 & 0,75 \\
\hline Kenyaman Lingkungan & 0,25 & 4 & 1 \\
\hline Total & 1 & & 4 \\
\hline \multicolumn{4}{|l|}{ Kelemahan Daya Tarik Wisata } \\
\hline Pemasaran & 0,15 & 3 & 0,45 \\
\hline Ekonomi Kreatif & 0,15 & 5 & 0,75 \\
\hline Prasarana & 0,25 & 5 & 1,25 \\
\hline Sarana Penunjang & 0,2 & 5 & 1 \\
\hline Sarana Pokok & 0,25 & 4 & 1 \\
\hline Total & 1 & & 4,45 \\
\hline \multicolumn{4}{|l|}{ Peluang Daya Tarik Wisata } \\
\hline Motivasi Wisatawan & 0,3 & 5 & 1,5 \\
\hline Dukungan Pemerintah daerah & 0,25 & 3 & 0,75 \\
\hline PMPM Mandiri Pariwisata & 0,25 & 4 & 1 \\
\hline Pertumbuhan Ekonomi Masyrakat & 0,2 & 3 & 0,6 \\
\hline Total & 1 & & 3,85 \\
\hline \multicolumn{4}{|l|}{ Ancaman Daya Tarik Wisata } \\
\hline Pesaing Dengan Wisata Sekitar & 0,4 & 5 & 2 \\
\hline Pencemaran Lingkungan & 0,2 & 4 & 0,8 \\
\hline Degradasi Sosial & 0,2 & 3 & 0,6 \\
\hline Konflik Vertikal & 0,2 & 4 & 0,8 \\
\hline Total & 1 & & 4,2 \\
\hline
\end{tabular}

Tabel 5. Analisis SWOT Nilai Tertimbang

\begin{tabular}{ccc}
\hline Faktor & Keterangan & Nilai \\
\hline Internal & Nilai Tertimbang Kekuatan Daya Tarik Wisata & 4 \\
& Nilai Tertimbang Kelemahan Daya Tarik Wisata & 4,45 \\
\cline { 2 - 3 } Eksternal & Selisih Negatif & $\mathbf{- 0 , 4 5}$ \\
& Nilai Tertimbang Peluang Daya Tarik Wisata & 3,85 \\
\cline { 2 - 3 } & Nilai Tertimbang Ancaman Daya Tarik Wisata & 4,2 \\
\cline { 2 - 3 } & Selisih Negatif & $\mathbf{- 0 , 3 5}$ \\
\hline
\end{tabular}




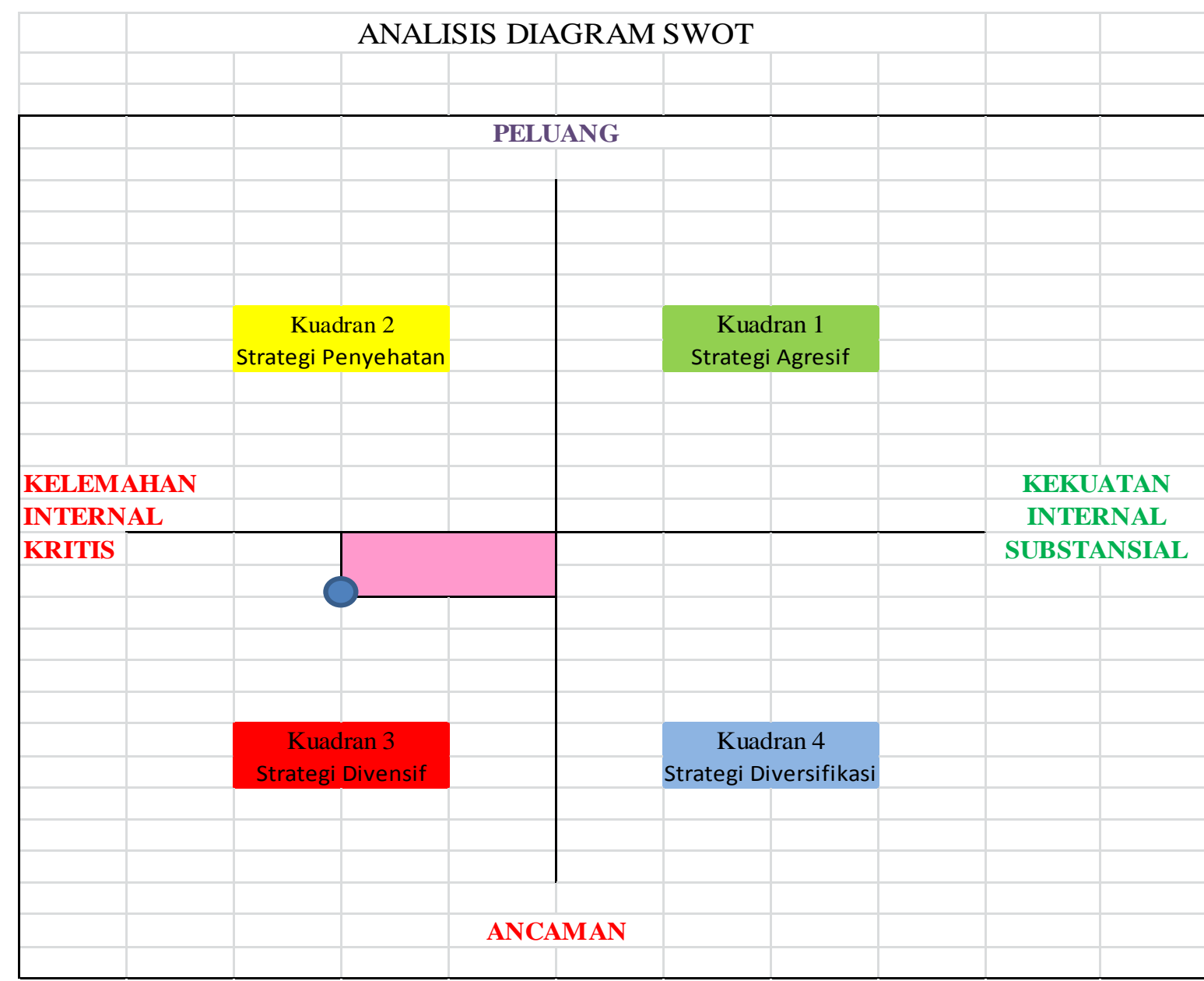

Daya tarik wisata pantai Malang Selatan sebagai sumber daya alam masih belum dibuat manejemen dengan baik maka akan masyarakat menjadikan sebagai alternatif mata pencaharian maka dibutuhkan pengembangan ekowisata pantai sebagai kegiatan ekonomi memungkinkan kedua untuk diversifikasi mata pencaharian dan berkelanjutan mengelola sumber daya alam menanggulangi kemiskinan , menurut Eshetu A (2014). Sumber daya alam di negara-negara berkembang berada di bawah ancaman besar sebagian karena kurangnya alternatif dan sebagian karena jenis mata pencaharian masyarakat. Dengan diversifikasi mata pencaharian masyarakat (terutama terhadap ecofriendly jenis), adalah mungkin untuk meminimalkan tekanan pada sumber daya alam.

Wisata Pantai Gua Cina belum maksimal di manfaatkan sebagai sumber daya alam yang produktif, seperti saran ( Ministry of Finance and Economic Development/MoFED, 2006), sumber daya alam merupakan dasar sosial dan pembangunan 
ekonomi untuk pengurangan kemiskinan, juga merupakan dasar sosial dan pembangunan ekonomi karena mereka adalah sumber barang dan jasa yang diperlukan untuk pengurangan kemiskinan dan pertumbuhan ekonomi.

Kabupaten Malang yaitu kabupaten harus mengutamakan pembangunan berkelanjutan hal ini penting untuk mengintegrasikan masalah lingkungan sejalan dengan kebijakan

(EPA/Environmental Protection Authority, 2000), dalam rangka untuk memastikan bahwa perkembangan masa depan di negara berkembang yang berkelanjutan adalah penting untuk mengintegrasikan masalah lingkungan menjadi kegiatan pembangunan sehingga masuknya prinsip-prinsip pembangunan berkelanjutan.

Pembangunan ekowisata pantai di Pantai Gua Cina dapat memainkan peran sentral dalam konservasi dan pembangunan masyarakat pedesaan, Ekowisata dapat memainkan peran sentral dalam konservasi dan pembangunan pedesaan (Nelson, 2004) yang biasanya pendekatan ecopembangunan di pengelolaan sumber daya alam. dan menekankan kebutuhan untuk merestrukturisasi masyarakat dan ekonomi untuk memastikan pembangunan yang bekerja dengan baik, bukan merusak, alam. sehingga hubungan antara masyarakat dan alam di hasil paradigma eco-development dengan reorganisasi aktivitas manusia sehingga menjadi sinergis dengan alam.

Dari hasil analisa SWOT melalui 4 tahap yang berlangsung menunjukan bahwa daya tarik wisata Pantai Gua cina berada pada kuadaran 3 dimana daya tarik wisata ini memiliki ancaman dan kelemahan. Adapun beberapa Kelemahan DTW :

1. Sarana transportasi umum untuk menuju Obyek Wisata Pantai belum ada

2. Kondisi lingkungan DTW yang masih kurang bersih

3. Tidak memiliki penerangan jalan sepanjang DTW ketika malam hari

4. Masih belum ada tindak lanjut tentang pembuatan cindera mata khas pantai tersebut.

5. Masih belum ada agen perjalanan di DTW tersebut 
6. Tidak terdapat hiburan lain dan atraksi budaya yang di perliatkan oleh warga sekitar

7. Tidak terdapat layanan internet di DTW tersebut.

8. Jaringan telepon kurang baik di DTW tersebut

9. Masih belum ada ATM di DTW tersebut

10. Masih belum terdapat hotel maupun penginaman karena wisatawan biasa melakukan campign di tempat tersebut

11. Tidak memiliki pos kesehatan di DTW tersebut

12. Sudah memiliki tempat tersebut tapi masih banyak yang perlu di perhatikan lagi

13. Masih belum adanya pemetaan tentang lokasi DTW tersebut

14. Tidak menggunakan media tersebut

15. Belum ada tenaga pemandu

16. Tidak memiliki pramuwisata

17. Belum ada naungan buat pramuwisata

18. Tidak ada pelatihan tentang pramuwisata

19. Pembangunan fisik masih di rasa lambat
20. Masih kurangnya pemahaman tentang adanya ekowisata

21. Sangat baik,wisata sangat puas dengan keindahan pantai yang di tawarkan.

22. Kurang sadarnya masyarakan akan pentingnya melestarikan budaya

23. Kebudayaan yang sudah tercampur karena masyrakat yang ada disekitar daerah tujuan wisata adalah pendatang

Ancaman DTW:

1. Kondisi pesaing daya tarik wisata Gua Cina sangat tinggi. Hal ini di buktikan karena pesaing yang memiliki keindahan dan kecukupan pada sarana dan prasana. Misalnya: pantai bajul mati dan Pantai Sendang Biru

2. Karakteristik Peran serta Masyarakat daya tarik wisata Gua cina ini sangat rendah hdikarenakan masyarakat yang tinggal di sekitar wisata nggan untuk di ajak berperan dalam pengembangan daya tarik wisata

Strategi difensife ditujukan untuk mempertahankan eksistensi perusahaan dari semakin ketatnya persaingan bisnis dan berbagai 
ketidakpastian eksternal yang sulit (terkadang tidak mungkin) dikontrol dan diprediksi. Strategi defensif seringpula dikenal sebagai survival strategy, yang cenderung terjadi dalam suasana krisis ekonomi.ada beberapa strategi yang dapat di lakukan di kuadran 3 ini. Meliputi: Divers.Konsentrik, diversifikasi Horisontal, Diversifikasi Konglomerasi.

1. Diversifikasi Konsentrik Menambah produk atau jasa baru, tetapi berhubungan, secara umum disebut diversifikasi konsentrik atau terfokus yaitu usaha Sovenir Khas.

2. Diversifikasi Horizontal Menambahkan produk atau jasa baru, yang tidak berkaitan, untuk pelanggan saat ini disebut diversifikasi horizontal. Strategi ini tidak seberesiko diversifikasi konglomerat karena perusahaan seharusnya sudah lebih dikenal dengan pelanggan saat ini yaitu menanam pohon Mangrove.

3. Diversifikasi Konglomerat

Menambah produk atau jasa baru, yang tidak berkaitan, disebut diversifikasi konglomerat yaitu membuka Home Stay bekerja sama dengan swasta.

\section{KESIMPULAN}

Dari hasil analisis SWOT disimpulkan bahwa nilai selisih tertimbang DTW(daya Tarik Wisata) Gua cina adalah lingkungan internal memiliki nilai negatif(-0,45) dan lingkungan eksternal memiliki nilai negatif $(-0,35)$ dengan demikian dapat di tarik kesimpulan bahwa posisi DTW Gua Cina masuk pada kuadran 3 (Tiga) yang artinya posisi ini pada posisi difensif. Hal ini di buktikan dengan kondisi pembangunan fisik masih di rasa lambat untuk pengembangan DTW di sekitar Pantai Gua Cina, Selain itu lingkungan yang kurang bersih juga menjadi salah satu kendala di wilayah tersebut, kendala lainnya yaitu adalah jaringan telepon yang sangat kurang sekali di DTW tersebut,ada pun tentang pembuatan cindera mata khas pantai tersebut tidak ada, di sisi lain fasilitas - fasilitas yang di miliki masih sangat kurang memadai seperti sarana transportasi umum,penerangan jalan, Pos Kesehatan di DTW, Mesin ATM yang jauh dengan 
DTW,Penginapan,pramuwisata,jaring an internet ini merupakan faktor kendala lainnya.

Analisa lingkungan eksternal yaitu disebabkan oleh Kondisi pesaing daya tarik wisata Gua Cina sangat tinggi. Hal ini di buktikan karena pesaing yang memiliki keindahan dan kecukupan pada sarana dan prasana. Misalnya: pantai Bajul Mati dan Pantai Sendang Biru.

Langkah langkah penanggulangan kemiskinan dapat dipercepat melalui koordinasi dan pengendalian yang lebih konkret dalam percepatan penanggulangan kemiskinan. Untuk itu, Bupati Kabupaten Malang sebaiknya membentuk Tim Koordinasi Penanggulangan Kemiskinan Daerah (TKPKD) di Kabupaten Malang.

Program dan kegiatan penanggulangan kemiskinan dapat dikelompokkan dalam 4 (empat) kelompok program atau klaster, yaitu :

1. Kelompok program bantuan sosial terpadu berbasis keluarga (Klaster I) Program bantuan sosial terpadu berbasis keluarga bertujuan untuk memenuhi hak dasar, pengurangan beban hidup
, dan perbaikan kualitas hidup penduduk miskin. Contohnya adalah Program Raskin, BLT dan Beasiswa bagi siswa miskin.

2. Kelompok program pemberdayaan masyarakat (Klaster II) Kelompok program penanggulangan kemiski nan berbasis pemberdayaan masyarakat bertuj uan untuk mengembangkan pote nsi dan memperkuat kapasitas kelompok masyarakat miskin untuk terlibat dalam pembangunan yang didasarkan pada prinsip-prinsip pemberdayaan masyarakat. Contohnya adalah PNPM Mandiri.

3. Kelompok program pemberdayaan usaha mikro dan kecil

(Klaster

Program penanggulangan kemis kinan berbasis pemberdayaan usaha ekonomi mikro dan kecil adalah program yang bertujuan untuk mempercepat pembangunan

ekonomi masyarakat dengan ber basis sumberdaya lokal. Contohnya adalah Kredit Usaha 
Rakyat (KUR) dan Kredit Usaha Bersama (KUBE).

4. Kelompok Program Pro-Rakyat (Klaster IV). Klaster IV ini mulai dicanangkan pada Pertemuan Nasional TKPKD seluruh Indonesia bulan Nopember di Jakarta.

Upaya penangkaran Penyu ini dilakukan pada pelestarian penyu sisik ini meliputi berbagai langkah penyelamatan, yaitu meliputi upaya pembinaan habitat tempat penyu bertelur, menunggui penyu bertelur dan kemudian menyelamatkan telur penyu dari hama dan predator, penetasan telur semi alamiah diberi tempat yang baik, perawatan anak penyu (tukik) untuk pelepasan di habitat asli, dan pembinaan masyarakat dalam upaya konservasi penyu sebagai satwa langka.

Peningkatan Pelestarian

Hutan bakau atau disebut juga hutan mangrove yang tumbuh di atas rawarawa berair payau yang terletak pada garis pantai dan dipengaruhi oleh pasang-surut air laut. Hutan ini letakkan di tempat-tempat di mana terjadi pelumpuran dan akumulasi bahan organik. Baik di teluk-teluk yang terlindung dari gempuran ombak, maupun di sekitar muara sungai di mana air melambat dan mengendapkan lumpur yang dibawanya dari hulu.

\section{UCAPAN TERIMAKASIH}

Artikel Ilmiah ini merupakan hasil dari kegiatan Penelitian kemudian disarikan menjadi Artikel Ilmiah ini dan dalam tulisan ini Kami sempatkan untuk menyampaikan banyak terimakasih atas terwujudnya tulisan ini kepada Dirjen Pendidikan Tinggi Cq. Kopertis Wilayah VII yang telah memberikan dukungan dana untuk kegiatan penelitian kali ini.

\section{DAFTAR PUSTAKA}

Badan Pusat Statistik (BPS), 2012, Kabupaten Malang dalam Angka 2012, Badan Pusat Statistik (BPS) Kabupaten Malang, Malang

Bambang., N., dkk., (1999). Pengembangan Model Pendampingan dan Pelatihan Bagi Perajin Industri Rumah Tangga Gerabah Di Desa Banyumulek Kec.Kediri Kabupaten Lombok Barat NTB. Malang: Unmer Malang. Penelitian PHB.VII.No.Kontrak.76/P2IPT/ DPPM/98/PHBVII/V/98.

Dirjen. PT Departemen 
Pendidikan dan Kebudayaan RI.

Dinas Kebudayaan dan Pariwisata Jatim,2012, Kebudayaan dan Pariwisata Jawa Timur Tahun 2012 Dalam Angka Tahun, Dinas Kebudayaan dan Pariwisata Propinsi Jawa Timur, Surabaya.

Environmental Protection Authority /EPA/ of Ethiopia (2000). Environmental Impact

Eshetu A (2014), Ecotourism as a viable strategy for livelihood diversification and sustainable natural resource management in Ethiopia (from eco-development paradigm point of view), Journal of Environmental Vol. 3(2), pp. $040-052$

Inskeep Edward, (1991), Tourism Planing An Integrated And Sustainable Development Approach, Van Nostrand Reinhold, New York

Ministry of Finance and Economic Development (MoFED) (2006). Ethiopia: Building on Progress-A Plan for Accelerated and Sustained Development to End Poverty PASDEP) (2005/062009/10); Volume I: Main Text. Addis Ababa, Ethiopia.

Nelson F (2004). The evolution and impacts of community-based ecotourism in northern Tanzania. International Institute for Environment and Development: Issue paper number 131.
Oka A.Yoeti, 1996, Guiding System SuatuPengantarPraktis, PT PradnyaParamita, Jakarta

Meter, Donald., S Van \& Carl E.Van Horn., 1975, The Policy Implementation Process: A Conceptual Frame Work, Beverly Hills, Sage Publication Inc.

$\begin{array}{cr}\text { Panuju, Bambang., } & \text { 1999, } \\ \text { PengadaanPerumahan } & \text { Kota }\end{array}$ dengan Peranserta Masyarakat Berpenghasilan Rendah. Alumni, Bandung.

Poerwanto, 2002, Dampak Pengembangan Obyek Pariwisata Pantai Pasir Putih Situbondo Terhadap Kesempatan Kerja,JurnalNasionalPariwisata, Vol.2, No.2, Desember.

Robby, 2001, WisataAlam, BukuPedomanIdentifikasi,

Pengembangan, Pengelolaan, Pemeliharaan, PemasaranObyekWisataAlam, YayasanBuenavita, Bogor.

Wahab, Salah, ed., 1992, PemasaranPariwisata, PT. PradnyaParamita, Jakarta.

Yuwono Sudarman dan Sugiono Sutomo, November 2008, Jurnal Ilmiah Pariwisata, STP Trisakti, Vol. 13 No. 3. hal 208. 
ISSN : $1410-7252$

Vol. 18 No. 01 Juni 2016 